\title{
Lemongrass Leaf Extract Attenuates Hydrocarbon-Induced Oxidative Stress and Macrocytic Hypochromic Anaemia in Rats
}

\author{
Christopher Ekpenyong \\ Department of Physiology, Faculty of Basic Medical Sciences, University of Uyo, Uyo, Nigeria
}

Email address:

chrisvon200@yahoo.com, chrisvon300@yahoo.com

\section{To cite this article:}

Christopher Ekpenyong. Lemongrass Leaf Extract Attenuates Hydrocarbon-Induced Oxidative Stress and Macrocytic Hypochromic Anaemia in Rats. International Journal of Ecotoxicology and Ecobiology. Vol. 2, No. 2, 2017, pp. 74-79. doi: 10.11648/j.ijee.20170202.13

Received: May 5, 2017; Accepted: June 3, 2017; Published: July 21, 2017

\begin{abstract}
The therapeutic use of medicinal plants and plant products to mitigate solvent/xenobiotic-induced haematological disorders has not been adequately explored. The aim of this study was to evaluate the effect of Cymbopogon citratus (C. citratus) leaf decoctions on gasoline vapour (GV)-induced haematological disorders and oxidative stress in rats. Seventy-two female rats weighing 180-200g were randomly selected and divided into six groups ( $\mathrm{n}=12$ per group). Animals in group 1 served as unexposed controls, while animals in group 2 were exposed to gasoline vapour (GV) alone for 35 days. Animals in groups 3, 4, and 5 were exposed to GV and co-administered C. citratus leaf extract (500 mg/kg, $1000 \mathrm{mg} / \mathrm{kg}$, and $1500 \mathrm{mg} / \mathrm{kg}$, respectively), and animals in group 6 were exposed to GV and co-administered vitamin C (200 $\mathrm{mg} / \mathrm{kg})$ for the same time period. Exposure of animals to GV alone significantly $(p<0.05)$ decreased packed cell volume (PCV), haemoglobin concentration (HB), total red blood cells (RBC), mean cell haemoglobin (MCH) and mean cell haemoglobin concentration (MCHC). Total white blood cells (WBC), WBC lineages and malondialdehyde (MDA) levels significantly increased $(p<0.05)$ compared to the corresponding values in the control group. Supplementation with $C$. citratus leaf decoction and vitamin $\mathrm{C}$ reversed these $\mathrm{GV}$-induced changes in haematological indices and MDA levels. Therefore, C. citratus leaf decoctions and vitamin $\mathrm{C}$ supplementation provided an ameliorative effect on $\mathrm{GV}$-induced haematotoxicity and oxidative stress in a rat model of gasoline exposure.
\end{abstract}

Keywords: Lemongrass, Gasoline Fumes, Haematotoxicity, Amelioration, Rat

\section{Introduction}

Gasoline is a complex mixture of hydrocarbons and additives and is primarily used in combustion engines as a motor fuel. It is also used as a diluent for paints and industrial solvents. Gasoline contains several compounds that are toxic to humans, such as benzene, toluene, ethylbenzene, and xylene (BTEX) as well as other additives [1].

Gasoline is derived from the fractional distillation of petroleum, and it has 5-10 carbon atoms. However, the relative concentrations of the components depend on the crude oil source and the refinery process. The volatile fractions of gasoline are released into the atmosphere at every stage of the production and marketing chains, thereby exposing workers to their potential adverse effects, including haematotoxicity $[2,3]$.

Several previous studies [4-7] have established a close association between exposure to gasoline compounds and haematotoxicity in humans.

Several potential mechanisms have been postulated for the haematotoxic effect of gasoline, including interference with cell cycle regulation and the expression of DNAdamage/repair genes, oxidative stress genes, growth factorrelated genes, and haematopoiesis-related genes, as well as bone marrow toxicity, haemolysis, and increased formation of methaemoglobin [3]. Central to these mechanisms is the induction of oxidative stress by gasoline component metabolites.

Although various synthetic antioxidants (e.g. vitamins A, $\mathrm{C}$, and E) have been shown to ameliorate gasoline-induced haematotoxicity in previous studies [8], adequate therapeutic coverage has been limited by the failures of modern medicine to provide holistic care and the disadvantages of multiple drug therapies as well as an inability to alleviate the 
pleotropic effects of the gasoline component metabolites. Therefore, recently, there has been renewed interest in medicinal plants owing to increased awareness of their health benefits. Antioxidants of plant origin typically do not induce the side effects associated with the use of synthetic antioxidants, such as butylatedhydroxytoluene (BHT), which has been found to cause haemorrhaging [9].

Medicinal plants are rich sources of nutrients and bioactive substances with anti-inflammatory, immunity-boosting, antioxidant, anti-carcinogenic, antimicrobial, anti-genotoxic, anti-apoptotic, and erythropoiesis-boosting effects [10]. Thus, these plants have the potential to provide holistic therapeutic coverage, and thereby improve human health and prevent acute and chronic diseases [10]. One such plant is Lemongrsass (Cymbopogon citratus (C. citratus)).

C. citratus is an aromatic perennial tropical plant that grows worldwide. C. citratus has long slender leaves of about $90 \mathrm{~cm}$ in length and $1.5 \mathrm{~cm}$ in breadth, The leaves give off a slight aroma of ginger when crushed. It is a member of the Poaceae family, and owing to its varied bioactive constituents, has extensive nutritional, therapeutic, and cosmetic applications. It has long been used as a traditional medicine for its antibacterial [11], anticarcinogenic [12], antiinflammatory [13], antioxidant, antimicrobial [14], and erythropoietic-boosting effects [10]. The antioxidant effect of $C$. citratus has been described, and it has been proposed as an alternative treatment for numerous diseases [15].

Several synthetic antioxidant vitamins, including A, C, and $\mathrm{E}$, have been shown to provide protective effects against $\mathrm{GV}$ induced haematotoxicity [3, 8]. These vitamins and other bioactive antioxidants are also found in vegetables, fruits, and other plants, such as C. citratus. However, their protective activities against $\mathrm{GV}$-induced detrimental health effects, including haematotoxicity, have not been adequately investigated. The aim of the present study was to assess the effect of $C$. citratus decoction on GV-induced haematotoxicity in rats.

\section{Materials and Methods}

Fresh C. citratus leaves were obtained from an agricultural farm in Uyo, Akwa Ibom State, Nigeria a few days prior to utilization. Identification and authentication was performed by a taxonomist (ID UHH 4686/Uyo) in the Department of Botany at the University of Uyo.

The leaves were rinsed, sundried, and pulverized into powder using an electric blender to provide $400 \mathrm{~g}$ of material. The powder was soaked with $4 \mathrm{~L}$ of hot water in a conical flask and allowed to stand for approximately $10 \mathrm{~h}$.

After filtering the solution through Whatman No. 2 filter paper, the filtrate was evaporated to dryness by heating in a water bath at $40^{\circ} \mathrm{C}$. The final solid extract was weighed with an electric balance (ACS-2E14; Surgifriend Medicals, Ltd., England), with a total yield of $30 \%$. The prepared extract was stored in glass bottles at $4^{\circ} \mathrm{C}$ and was dissolved in physiological saline at $100 \mathrm{mg} / \mathrm{mL}$.

\subsection{Phytochemical/Nutritional Screening of C. Citratus Leaf Extract}

The phytochemical analysis of the leaf extracts was carried out to determine the levels of tannins, phenolics, saponins, alkaloids, deoxysugars, and anthraquinones as described by Trease and Evans [16] and Sofowora [17]. Nutrient constituents were determined per $100 \mathrm{~g}$ of extract as described previously [18].

\subsection{Experimental Animals}

Seventy-two mature female Wistar albino rats weighing $180-200 \mathrm{~g}$ were obtained from the animal house at the Faculty of Basic Medical Sciences, University of Uyo, Nigeria. The rats were randomly divided into six groups with 12 rats per group as follows: Group 1, normal (unexposed) control; Group 2, Test group exposed to GV only; Group 3, Test group exposed to $\mathrm{GV}$ and concomitantly treated with $C$. citratus extract ( $500 \mathrm{mg} / \mathrm{kg}$; low dose) daily, Group 4, Test group exposed to GV and concomitantly treated with (1000 $\mathrm{mg} / \mathrm{kg}$; medium dose) daily; Group 5, Test group exposed to $\mathrm{GV}$ and concomitantly treated with (1500 mg/kg; high dose) daily; and Group 6, Test group exposed to $\mathrm{GV}$ and concomitantly treated with vitamin C (200 mg/kg).

\subsection{Determination of $L D_{50}$}

The median lethal dose $\left(\mathrm{LD}_{50}\right)$ was determined as previously described $[19,20]$. From the $\operatorname{LD}_{50}(5000 \mathrm{mg} / \mathrm{kg})$, the low, medium, and high doses were calculated using a standard formula as $500 \mathrm{mg} / \mathrm{kg}, 1000 \mathrm{mg} / \mathrm{kg}$, and 1500 $\mathrm{mg} / \mathrm{kg}$, respectively.

The rats were acclimatized for one week before the starting the experiment. Each animal was housed in a standard wooden cage with wood shavings as bedding, which was regularly replaced. The experiment was performed under standard laboratory conditions (at room temperature [28 \pm $8^{\circ} \mathrm{C}$ ], $45 \%$ humidity, with a $12-\mathrm{h}$ light/dark cycle). All animals were fed normal rat pellets (Bendel Feed and Flour Mill Ltd, Benin) and allowed free access to food and water throughout the experimental period.

All research protocols were performed at the University of Uyo according to Nigerian and international laws governing the acceptable use of laboratory animals.

The protocol was approved by the Institutional Animal Care and Use Committee.

\subsection{Exposure to $G V$}

The animals in the test group were exposed to unleaded gasoline purchased from a Nigerian National Petroleum Cooperation (NNPC) refuelling station on Itam - Ikot Ekpene Road in Uyo, Nigeria. The rats in the exposed groups were housed in their cages and exposed to $\mathrm{GV}$ in an exposure chamber $(80 \times 60 \times 100 \mathrm{~cm})$. Rats in the control group were kept in a GV-free section of the experimental house. Two calibrated $500-\mathrm{mL}$ beakers each containing $100 \mathrm{~mL}$ of petrol were put in the modified chamber where the exposed groups 
were placed, and then the rats were allowed to inhale the GV in the chamber for $6 \mathrm{~h} \mathrm{(9} \mathrm{am-3} \mathrm{pm)} \mathrm{daily} \mathrm{for} 35$ consecutive days. At the end of the exposure period, the gasoline was removed; the initial and final volumes were recorded before and after exposure, respectively. The daily difference in volume was used to estimate the relative vapour exposure. The average exposure was approximately $80 \mathrm{~mL} /$ day.

\subsection{Treatment of Rats with C. citratus Leaf Extracts and Vitamin C}

Rats in groups 3, 4, and 5 were treated with decoctions prepared from $500 \mathrm{mg} / \mathrm{kg}, 1000 \mathrm{mg} / \mathrm{kg}$, and $1500 \mathrm{mg} / \mathrm{kg}$ of C. citratus extract, respectively, while rats in group VI were treated with $200 \mathrm{mg} / \mathrm{kg}$ (i.e. the normal prophylactic dose) of vitamin C [21]. The C. citratus decoctions and watersolubilized vitamin $\mathrm{C}$ were administered by oral gavage (using an intragastric syringe) for the final 14 days of the 35day GV exposure.

After the exposure period, the rats were sacrificed by anaesthetizing with chloroform. Blood was collected by cardiac puncture into specimen bottles with and without anticoagulant for haematological analysis and MDA estimation respectively. Serum samples were stored at $-80^{\circ} \mathrm{C}$ until analysis.

Total blood count including total leucocyte and differential counts and other haematological parameters were measured within $2 \mathrm{~h}$ of blood sample collection using the SYSMEX KX-21 Automated Haematology Analyzer (Kobe, Japan).

Statistical analysis was performed using the Statistical Package for Social Sciences (SPSS), version 20.0.

Data obtained were analysed using descriptive statistics and reported as the mean \pm standard deviation (SD). Analysis of variance (ANOVA) was also used. Duncan's multiple range test was used to compare results between groups, determine the direction of significance, and to analyse the effect of the $C$. citratus decoction on the haematoxicity of GV. Differences with $p$ values less than 0.05 were considered statistically significant.

\section{Results}

Analysis of the bioactive natural constituents of the $C$. citratus leaf extract in the present study showed moderate levels of saponins, tannins and flavonoids and relatively low levels of alkaloids, and anthraquinones. Nutritional constituents as determined previously [10] revealed the presence of crude protein (2.5 g), crude fibre (2.92 g), carbohydrate $(36.02 \mathrm{~g})$, potassium $(420 \mathrm{mg})$, sodium $(14.30$ $\mathrm{mg})$, iron (18.4 mg), magnesium (32.10 mg), zinc (2.35 mg), copper $(0.368 \mathrm{mg})$, selenium $(1.32 \mathrm{mcg})$, vitamin $\mathrm{C}(3.65$ $\mathrm{mg})$, pyridoxine $(0.07 \mathrm{mg})$ and folate $(78 \mathrm{mcg})$.

Exposure of experimental animals to $\mathrm{GV}$ alone caused significant decreases in $\operatorname{PCV}(p=0.00)$, haemoglobin $(\mathrm{Hb})$ concentration $(\mathrm{p}=0.004), \mathrm{RBC}(\mathrm{p}=0.03)$, platelet $(\mathrm{PL})$ counts, and reticulocyte counts compared to corresponding levels in control animals.

Co-administration of $C$. citratus decoction at various concentrations $(500 \mathrm{mg} / \mathrm{kg}, 1000 \mathrm{mg} / \mathrm{kg}$, and $1500 \mathrm{mg} / \mathrm{kg}$ ) and vitamin $\mathrm{C}(200 \mathrm{mg} / \mathrm{kg})$ increased $\mathrm{PCV}, \mathrm{Hb}$, and $\mathrm{RBC}$, while PL and reticulocyte counts significantly decreased compared to corresponding levels in GV-alone group (Table 1).

Table 2 shows that exposure of the experimental animals to $\mathrm{GV}$-alone caused significant decreases in $\mathrm{MCH}$ and SOD levels, and a non-significant decrease in MCHC levels compared to corresponding levels in the control group. Also, MCV and MDA levels significantly increased following exposure to $\mathrm{GV}$ alone. Co-administration of $C$. citratus decoction at various concentrations $(500 \mathrm{mg} / \mathrm{kg}, 1000 \mathrm{mg} / \mathrm{kg}$, and $1500 \mathrm{mg} / \mathrm{kg})$ and vitamin $\mathrm{C}(200 \mathrm{mg} / \mathrm{kg})$ caused a significant increase in $\mathrm{MCH}$ levels, and significant decreases in MCV and MDA levels. Non-significant decreases in $\mathrm{MCHC}$ and SOD levels were found in animals co-treated with $500 \mathrm{mg} / \mathrm{kg}$ and $1000 \mathrm{mg} / \mathrm{kg}$ of C. citrates decoctions, while non-significant increases in MCHC and SOD levels were found in animals co-administered with $1500 \mathrm{mg} / \mathrm{kg}$ of C. citratus decoction and $200 \mathrm{mg} / \mathrm{kg}$ of vitamin C respectively.

Total WBC counts and WBC lineages including neutrophil counts $(p=0.000)$, lymphocyte counts $(p=0.004)$, monocyte counts $(\mathrm{p}=0.00)$, eosinophil counts $(\mathrm{p}=0.003)$ and basophil counts significantly increased in animals exposed to GV alone compared to corresponding levels in the control animals.

Supplementation with $C$. citratus decoctions and vitamin $\mathrm{C}$ reversed these $\mathrm{GV}$-induced changes in total $\mathrm{WBC}$ and $\mathrm{WBC}$ lineages (Table 3).

Table 1. Effect of C. citratus decoctions and ascorbic acid supplementation on some haematological profile of GV-induced haematotoxicity model in rats.

\begin{tabular}{llllll}
\hline Group & PCV (\%) & Hb $(\mathbf{m g d} / \mathbf{L})$ & RBC $\left(\mathbf{X 1 0 ^ { 6 }} / \mathbf{m m}^{\mathbf{3}}\right)$ & PL (\%) & Reticulocyte counts (\%) \\
\hline 1 & $40.75 \pm 1.89^{\mathrm{c}}$ & $13.58 \pm 2.81^{\mathrm{a}}$ & $7.33 \pm 0.42^{\mathrm{b}}$ & $645.33 \pm 63.13^{\mathrm{d}}$ & $153.50 \pm 7.99^{\mathrm{a}}$ \\
2 & $21.15 \pm 1.06^{\mathrm{a}}$ & $7.05 \pm 1.79^{\mathrm{b}}$ & $6.40 \pm 0.28^{\mathrm{a}}$ & $662.50 \pm 13.54^{\mathrm{c}}$ & $190.00 \pm 8.49^{\mathrm{b}}$ \\
3 & $28.17 \pm 1.17^{\mathrm{b}}$ & $9.39 \pm 1.87^{\mathrm{c}}$ & $6.50 \pm 0.24^{\mathrm{a}}$ & $509.50 \pm 10.64^{\mathrm{b}}$ & $180.50 \pm 8.17^{\mathrm{b}}$ \\
4 & $27.78 \pm 1.83^{\mathrm{b}}$ & $9.26 \pm 1.11^{\mathrm{c}}$ & $6.60 \pm 0.38^{\mathrm{a}}$ & $597.50 \pm 14.41^{\mathrm{c}}$ & $151.33 \pm 9.16^{\mathrm{a}}$ \\
5 & $26.15 \pm 1.43^{\mathrm{b}}$ & $8.72 \pm 1.62^{\mathrm{c}}$ & $6.98 \pm 0.37^{\mathrm{b}}$ & $330.33 \pm 10.66^{\mathrm{a}}$ & $154.50 \pm 5.572^{\mathrm{a}}$ \\
6 & $28.25 \pm 2.99^{\mathrm{b}}$ & $9.42 \pm 1.600^{\mathrm{c}}$ & $7.07 \pm 0.19^{\mathrm{b}}$ & $576.0 \pm 13.07^{\mathrm{c}}$ & $152.60 \pm 5.10^{\mathrm{a}}$ \\
\hline
\end{tabular}

The different superscripts are significant at $5 \%(\mathrm{p}<0.05)$, PVC (Packed cell volume), Hb (Haemoglobin), RBC (Red blood cells), PL (Platelets). 
Table 2. Effect of C. citratus decoctions and ascorbic acid supplementation on red blood cell and oxidative stress markers.

\begin{tabular}{lllll}
\hline Parameters & MCH $(\mathbf{p g})$ & MCHC $\left(\mathbf{m m}^{3}\right)$ & MCV $(\mathbf{f t})$ & SOD $(\mathbf{m m o l} / \mathbf{L})$ \\
\hline Groups & & & & \\
\hline 1 & $17.83 \pm 1.47^{\mathrm{b}}$ & $33.47 \pm 2.04^{\mathrm{b}}$ & $48.10 \pm 2.74^{\mathrm{a}}$ & $10.530 \pm 1.240^{\mathrm{b}}$ \\
2 & $15.00 \pm 1.41^{\mathrm{a}}$ & $30.40 \pm 4.44^{\mathrm{b}}$ & $54.90 \pm 2.08^{\mathrm{b}}$ & $7.064 \pm 1.520^{\mathrm{a}}$ \\
3 & $18.17 \pm 1.94^{\mathrm{b}}$ & $25.92 \pm 4.52^{\mathrm{a}}$ & $45.68 \pm 2.64^{\mathrm{a}}$ & $7.840 \pm 1.380^{\mathrm{a}}$ \\
4 & $17.50 \pm 2.07^{\mathrm{b}}$ & $27.92 \pm 3.72^{\mathrm{a}}$ & $50.35 \pm 2.66^{\mathrm{a}}$ & $8.24 \pm 2.24^{\mathrm{a}}$ \\
5 & $18.00 \pm 0.89^{\mathrm{b}}$ & $31.53 \pm 1.87^{\mathrm{b}}$ & $47.40 \pm 1.38^{\mathrm{a}}$ & $9.76 \pm 2.81^{\mathrm{b}}$ \\
6 & $18.83 \pm 2.32^{\mathrm{b}}$ & $31.30 \pm 1.48^{\mathrm{b}}$ & $46.80 \pm 2.20^{\mathrm{a}}$ & $7.24 \pm 0.39^{\mathrm{b}}$ \\
\hline
\end{tabular}

Same letters mean not significantly different $(\mathrm{p}>0.05)$,

Different letters means significantly different $(\mathrm{p}<0.05)$.

Table 3. Effect of C. citratus decoctions and ascorbic acid supplementation on total white blood cell and white blood cell lineages of GV-induced haematotoxicity model in rat.

\begin{tabular}{|c|c|c|c|c|c|c|}
\hline Group & Total WBC $\left(\times 10^{3} / \mathrm{mm}^{3}\right)$ & $\begin{array}{l}\text { Neutrophil } \\
\text { Counts (\%) }\end{array}$ & $\begin{array}{l}\text { Lymphocyte } \\
\text { Counts (\%) }\end{array}$ & $\begin{array}{l}\text { Monocyte } \\
\text { Counts (\%) }\end{array}$ & $\begin{array}{l}\text { Eosinophil } \\
\text { Counts (\%) }\end{array}$ & $\begin{array}{l}\text { Basophil } \\
\text { Counts (\%) }\end{array}$ \\
\hline 1 & $3.13 \pm 1.11^{\mathrm{a}}$ & $0.23 \pm 0.11^{\mathrm{a}}$ & $3.43 \pm 2.69^{\mathrm{a}}$ & $0.07 \pm 0.02^{\mathrm{a}}$ & $0.11 \pm 0.00^{\mathrm{a}}$ & $0.00 \pm 0.00^{\mathrm{a}}$ \\
\hline 2 & $12.75 \pm 1.77^{\mathrm{c}}$ & $1.00 \pm 0.28^{\mathrm{c}}$ & $7.90 \pm 0.99^{c}$ & $0.20 \pm 0.01^{\mathrm{b}}$ & $0.13 \pm 0.04^{\mathrm{c}}$ & $0.10 \pm 0.14^{\mathrm{c}}$ \\
\hline 3 & $10.72 \pm 1.08^{b}$ & $1.07 \pm 0.23^{\mathrm{c}}$ & $6.67 \pm 0.82^{\mathrm{c}}$ & $0.11 \pm 0.05^{\mathrm{b}}$ & $0.03 \pm 0.02^{\mathrm{a}}$ & $0.06 \pm 0.10^{\mathrm{b}}$ \\
\hline 4 & $9.55 \pm 0.51^{\mathrm{b}}$ & $0.55 \pm 0.34^{\mathrm{a}}$ & $5.58 \pm 0.87^{\mathrm{b}}$ & $0.11 \pm 0.05^{\mathrm{b}}$ & $0.03 \pm 0.01^{\mathrm{a}}$ & $0.01 \pm 0.01^{\mathrm{a}}$ \\
\hline 5 & $9.40 \pm 0.53^{b}$ & $0.42 \pm 0.30^{\mathrm{a}}$ & $5.92 \pm 0.50^{\mathrm{b}}$ & $0.08 \pm 0.03^{\mathrm{a}}$ & $0.06 \pm 0.08^{\mathrm{b}}$ & $0.01 \pm 0.01^{\mathrm{a}}$ \\
\hline 6 & $9.27 \pm 0.31^{b}$ & $0.75 \pm 0.12^{b}$ & $7.00 \pm 0.41^{\mathrm{c}}$ & $0.07 \pm 0.02^{\mathrm{a}}$ & $0.00 \pm 0.00^{\mathrm{a}}$ & $0.00 \pm 0.00^{\mathrm{a}}$ \\
\hline
\end{tabular}

The different superscripts are significant at $5 \%(\mathrm{p}<0.05)$.

\section{Discussion}

In agreement with the findings of previous studies, results of the present study showed that exposure to GV decreased several erythropoiesis-modulated haemocytic variables (PCV, $\mathrm{Hb}, \mathrm{RBC}, \mathrm{MCH}$, and $\mathrm{MCHC}$ ) and caused significant increases in reticulocyte counts, MCV and MDA levels and total WBC and WBC lineage cell (neutrophils, lymphocytes, monocytes, eosinophils and basophil) counts, compared to the control group [1]. However, when C. citratus decoction $(500 \mathrm{mg} / \mathrm{kg}, 1000 \mathrm{mg} / \mathrm{kg}$, and $1500 \mathrm{mg} / \mathrm{kg})$ or vitamin C (200 $\mathrm{mg} / \mathrm{kg}$ ) was co-administered to the animals in groups $3,4,5$, or 6, respectively, the $\mathrm{GV}$-induced changes in the haematological parameters and MDA were reversed in a dose-dependent manner. Obviously, the aforementioned changes in haematological parameters (specifically significant increases in MDA, MCV, and decreases in $\mathrm{PCV}$, $\mathrm{Hb}, \mathrm{MCH}$, and $\mathrm{MCHC}$ ) of animals exposed to $\mathrm{GV}$ alone indicate $\mathrm{GV}$-induced lipid peroxidation (evidence of oxidative stress), and macrocytic hypochromic anaemia.

The present data provide additional evidence to support previous epidemiological and clinical studies that demonstrated a close association of exposure to gasoline compounds with haematotoxicity [2, 4-7] and the erythropoiesis-boosting (haematoprotective) effect of $C$. citratus leaf extracts [10]. Although several mechanisms have been posited to underlie GV-induced haematoxicity, induction of oxidative stress is central to the pathophysiology of $\mathrm{GV}$-induced haematotoxicity. Exposure to $\mathrm{GV}$ is associated with increased generation of reactive metabolites, leading to oxidative stress and oxidative damage to RBC [8]. Other effects include covalent binding and damage to DNA, impaired enzyme activities, cell-cycle suppression, myelosuppression, and aplastic anaemia [2]. Numerous established studies have confirmed that the most common cause of macrocytic anaemia is impaired DNA synthesis. However, the significant increase in reticulocyte count in the present study indicates associated hemolysis.

Furthermore, oxidative damage to DNA can cause activation of proto-oncogenes, suppression of $\mathrm{p} 53$, and leukaemia [4]. Suppression of growth factor- and haemopoiesis-related genes has also been observed [5]. Some gasoline compounds, such as benzene, have been shown to cause degeneration of bone marrow, aplastic anaemia, leukaemia, and changes in the dynamics of erythropoiesis [3, 22, 23]. Therefore, the ameliorative effect of $C$. citratus on $\mathrm{GV}$-induced haematotoxicity observed in the present study is partly due to the synergistic effects of its antioxidative, haematoprotective and erythropoiesis-boosting bioactive constituents against these GV-mediated pathological processes leading to qualitative and quantitative deficiency of $\mathrm{Hb}$, total $\mathrm{RBC}$ counts and RBC indices. Evaluation of the phytochemical and nutritional constituents of fresh $C$. citratus leaf extract in a previous and present study showed that several C. citratus constituents, including phytochemicals (saponins, polyphenols, tannins, flavonoids, and alkaloids); vitamins (vitamins A, C, E, folate, thiamine, niacin, pyridoxine, and riboflavin); minerals and trace elements (magnesium, zinc, copper, selenium and iron), electrolytes [10], and essential oil constituents (geraniol, myrcene, linalool, limonene, $\beta$-ionone, and citral), show antioxidative effects in human and animal cells [24]. Other important nutrients identified in $C$. citratus extract include carbohydrates, protein, and fat. These nutrient-rich constituents are precursors of erythropoiesis, and the antioxidative constituents can alleviate GV-induced oxidative stress and suppress other pathophysiological processes leading to GV-induced haematotoxicity.

In a previous study [10], the authors showed findings 
similar to those of the present study: that consumption of infusions prepared from $C$. citratus extracts was associated with a significant increase in $\mathrm{PCV}, \mathrm{HB}$, and $\mathrm{RBC}$ in human volunteers.

Indeed, there are numerous reports on the antioxidant activity of $C$. citratus as well as its potential to inhibit many drug/chemical-induced adverse health effects. For example, studies by Arhoghro et al., [25], Koh et al., [15], and Rahim et al. [26] demonstrated the ameliorative effect of $C$. citratus leaf extracts on chemical-induced liver damage (by cisplatin, carbon tetrachloride, and hydrogen peroxide, respectively). Additionally, Gayathri et al., [27] have observed that $C$. citratus extract produces marked attenuation of isoprenoidinduced cardiotoxicity and lipid peroxidation in rats. Common findings in these studies were improvement in the levels of antioxidant enzymes (SOD, CAT, and GSH) and suppression of the oxidative stress marker MDA. Findings of the present study are consistent with the aforementioned studies and provide support for the antioxidant potential of $C$. citratus decoction in mitigating GV-induced haematotoxicity.

While the erythropoiesis-modulated haemocytic variables significantly decreased in GV-alone group, total WBC and differentials showed the converse. The increase in total WBC was largely due to increase in the numbers of circulating neutrophils, eosinophils, and lymphocytes. These findings are similar to those previously observed in acute and chronic inflammatory processes and confirm the induction of inflammation as a pathogenic step in GV - induced haematotoxicity. Studies by others have shown that exposure to $\mathrm{GV}$ could induce local inflammatory processes and subsequently chronic inflammation. This is evidenced by increase markers of acute inflammation such as increase mucosal neutrophils, mast cells, interleukin-8, leukocytosis, myeloperoxidase, and glutathione [28, 29].

Neutrophil polymorphs are the first cells involve in many acute inflammatory lesions, followed by increase monocyte counts which become phagocytic and large in tissues and are called macrophages. Lymphocytes increase in the later stages of acute inflammation and persist in chronic inflammation giving a mixed picture of acute and chronic inflammatory cells as observed in the present study. Conversely, coadministration of $C$. citratus decoctions to rats in G3, G4 and G5 and Vitamin C to G6 caused decreases in total WBC and fluctuations in WBC differentials.

These findings confirm a previous human study [10] with similar results, and indicate the anti-inflammatory potential of $C$. citratus extract as previously reported. Carbajal et al., [30] found that hot water extract of dried C. citratus leaves elicited anti-inflammatory effects against the carrageeninduced edema. Likewise it was demonstrated that, intraperitoneal (i.p) administration of $5 \mathrm{ml}$ of $C$. citratus oil suppressed leukolyte recruitment into the peritoneal cavity including neutrophil accumulation [13]. Also, $0.0125 \%$ to $0.1 \%$ C citratus oil was found to suppress the activation of neutrophils by the tumor necrosis factor (TNF- $\alpha$ ) [13].

In a related study by Gbenou et al. [31], C. citratus EO displayed significant dose dependent edema (formol- induced) inhibition effect over time, and a strong analgesic and antipyretic properties similar to that induced by $50 \mathrm{mg} / \mathrm{kg}$ of acetyl salicylate, further demonstrating its antiinflammatory effect. The mechanisms underlying the antiinflammatory actions of $C$. citratus extract is posited to include inhibition of a complex immune-inflammatory mechanism and prostaglandin biosynthesis leading to pyrogens and prostaglandins release respectively [31]. These effects are comparable to the effect of salicylate drugs and non-steroidal anti-inflammatory drugs [31, 32]. Also, $C$. citratus EO is conceived to block the excitation of neuronal ends induced by pro-inflammatory substances. Aldehyde and Ketone molecules are the major molecules in C. citratus EO responsible for its anti-inflammatory effects.

\section{Conclusion}

The results of this study demonstrate that $C$. citratus decoction has ameliorative effects on GV-induced oxidative stress and haemato-toxicity in rats owing to its anti-oxidative, anti-inflammatory and erythropoiesis boosting activities. The results also suggest a greater effect of gasoline-induced haematotoxicity on erythropoiesis-modulated haemocyte variables. This is consistent with the results of a previous study [10] and provides additional support for the hypothesis that the $C$. citratus mediated increase in $\mathrm{PCV}, \mathrm{HB}$, and $\mathrm{RBC}$ may be elicited by an effect on the stimulant cytokine EPO [10]. Further studies to evaluate the effect of $C$. citratus decoction on erythropoietin (EPO) activities are needed.

\section{References}

[1] Ekpenyong, C. E., Asuquo, A. E. Recent advances in occupational and environmental health hazards of workers exposed to gasoline compounds: toxicology review. Int $J$ Occup Med Environ Health. 2017, 30, 1-26. https://doi.org/10.13075/ijomeh.1896.00800.

[2] Yoon, B., Hirabayashi, Y., Kawasaki, Y., Kodama, Y., Kaneko, T., Kim, A.Y, et al. Mechanism of action of benzene toxicity: cell cycle suppression in hematopoietic progenitor cell (CFU-GM). Exp Hematol. 2001, 29, 278-285.

[3] Udonwa, N. E., Uko, E. K., Ikpeme, B. M., Ibanga, I. A., Okon, B. O. Exposure of petrol station attendants and auto mechanics to premium motor spirit fumes in Calabar, Nigeria. J Environ Public Health. 2009. dx.doi.org/10.1155/2009/281876 Accessed: 28/12/2014.

[4] Qu, Q., Shore, R., Li, G., Jin, X., Chen, L. C., Cohen, B., et al. Hematological changes among Chinese worker with a broad range of benzene exposures. Am J Ind Med. 2002, 42, 275285.

[5] Okoro, A. M., Ani, E. J., Ibu, J. O., Akpogomeh, B. O. Effect of petroleum products inhalation on some haematological indices of fuel attendants in Calaber Metropolis, Nigeria. Nig J Physiol Sci. 2006, 21, 71-75.

[6] Sahb, A. A. A. Hematological assessment of gasoline exposure among petrol filling workers in Baghdad. J Fac Med Baghdad. 2011, 53, 396-400. 
[7] Tunsaringkarn, T., Soogarun, S., Palasuwa, A. Occupational exposure to benzene and changes in hematological parameters and urinary trans, trans-muconic acid. Int J Occup Environ. 2013, 4, 45-49.

[8] Sedky, A., Elsawy, H. Protective effect of vitamin C and E against gasoline vapours induced heamatological and biochemical changes in male rats. J Scientific Res. 2015, 7, 139-149.

[9] Ndhlala, A. R., Moyo, M., Van Staden, J. Natural antioxidants: fascinating or mythical biomolecules? Mol. 2010, 15, 6905-6930.

[10] Ekpenyong, C. E., Daniel, N. E., Antai, A. B. Bioactive natural constituents from lemongrass tea and erythropoiesis boosting effects: potential use in prevention and treatment of anemia. J Medicinal Food. 2015, 18, 118-127.

[11] Wannissorn, B., Jarikasem, S., Siriwangchai, T., Thubthimthed, S. Anti-bacterial properties of essential oils from Thai medicinal plants. Fitoterapia. 2005, 76, 233-236.

[12] Puatonachokchai, R., Kishida, H., Denda, A., Murata, N., Konishi, Y., Vinitketkumnuen, U. Inhibitory effects of lemon grass (Cymbogon citratus, stapf) extract on the early phase of hepatocarcinogenesis after initiation with diethylnitrosamine in male Fischer 344 rats. Cancer Lett. 2002, 183, 9-15.

[13] Abe, S., Maruyama, N., Hayama, K., Inouye, S., Oshima, F., Yamaguchi, H. Suppression of neutrophil recruitment in mice by geranium essential oil. Mediators Inflamm. 2004, 13:21-24.

[14] Masuda, T., Odaka, Y., Ogawa, N., Nakamoto, K., Kuninaga, H. Identification of geranic acid, a tyrosinase inhibitor in lemongrass (Cymbopogon citratus). J Agric Food Chem. 2008, 56, 597-601.

[15] Koh, P. H., Mokhtar, R. A. M., Iqbal, M. Antioxidant potential of Cymbopogon citratus extracts alleviation of carbon tetrachloride-induced hepatic oxidative stress and toxicity. Hum Exp Toxicol. 2012, 31, 81-91.

[16] Trease, G. E., Evans, W. C. A Textbook of Pharmacognosy. $13^{\text {th }}$ Ed., Blaire, Tindall, London, Pp.100-101, 1989.

[17] Sofowora, A. "Medicinal plant and traditional medicine in Africa", $2^{\text {nd }} E d .$, Spectrum Books Ltd, Ibadan, Nigeria. Pp 289, 1993.

[18] Ekpenyong, C. E., Davies, K., Antai, E. E. Cymbopogon citratus Stapf (Dc) extract ameliorates atherogenic cardiovascular risk in diabetes-induced dyslipidemia in rats. Br J Med Medical Res, 2014, 4, 4695-4709.

[19] Lorke, D. A new approach to practical acute toxicity testing. Arch Toxicol. 1983, 53, 275-287.

[20] Ekpenyong, C. E., Akpan, E. E., Udo, N. S. Phytochemistry and toxicity studies of Telferia Occidentalis aqueous leaves extracts on liver biochemical indices in wistar rats. Am J Med Sci. 2012, 2, 103-110.
[21] Uboh, F., Ebong, P., Udosen, E. Effect of vitamin C on Gasoline vapor induced reproductive toxicity in female rats. Turk Jem. 2010, 14, 26-30.

[22] Yardley-Jones, A., Anderson, D., Parke, D. V. The toxicity of benzene and its metabolism and molecular pathology in human risk assessment. Br J Ind Med. 1991, 48, 437-444.

[23] Carletti, R., Romano, D. Assessing health risk from benzene pollution in an urban area. Environ Monit Assess. 2002, 80, 135-148.

[24] Saeio, K., Chaiyana, W., Okonogi, S. Antityrosinase and antioxidant activities of essential oils of edible Thai plants. Drug Discov Ther, 2011, 5, 144-149.

[25] Arhoghro, E. M., Kpomah, D. E., Uwakwe, A. A. Curative Potential of Aqueous Extract of Lemon Grass (Cymbopogon citratus) on Cisplatin Induced Hepatotoxicity in Albino Wistar Rats. J Phys Pharm Adv. 2012, 2, 282-294.

[26] Rahim, S. M., Taha, E. M., Al-janabi, M. S., Al-douri, B. I., Simon, K. D., Mazian, A. G. Hepatoprotective effect of Cymbopogon citratus aqueous extract against hydrogen peroxide-induced liver injury in male rats. Afr $J$ Tradit Complement Altern Med. 2014, 11, 447-451.

[27] Gayathri, K., Jayachandran, K. S., Vasanthi, H. R., Rajamanickam, G. V. Cardioprotective effect of lemongrass as evidenced by biochemical and histopathological changes in experimentally induced cardiotoxicity. Hum Exp Toxicol. 2011, 30, 1073-1082.

[28] Wooden, M. A., Hauser, R., Liu, Y., Smith, T. J., Siegel, P. D., Lewis, D. M., Tollerud, D. J., Christiani, D. C. Molecular markers of acute upper airway inflammation in workers exposed to fuel-oil ash. Am J Respir Crit Care Med. 1998, $158,182-187$.

[29] Grebic, D., Jakovac, H., Mrakovcic-Sutic, I., Tomac, J., Bulog, A., Micovic, V., Radosevic-Stastic, B. Short-term exposure of mice to gasoline vapor increases the metallothion expression in the brain, lungs and kidney. Histol Histopathol. 2007, 22, 593-601.

[30] Carbajal, D. E., Casaco, L., ArruzaZabala, L., Gonzalez, R., Tolon, Z. Pharmacological study of Cymbopogon citratus leaves. J Ethnopharmacol. 1998, 25, 103-107.

[31] Gbenou, J. D., Ahounou, J. F., Akakpo, H. B., Laleye, A., Yaji, E., Gbaguidi, F., Baba-Moussa, L., Barboux, R., Danson, P., Moudachiron, M., Kotchoni, S. O. Phytochemical composition of cymbopogon citratus and eucalyptus citriodora essential oils and their anti-inflammatory and analgesic properties on Wister rats. Mol Biol Rep. 2012. doi 10.1007/sii033-012-2155-1.

[32] Abena, A. A., Gbenou, I. D., Yayi, E., Moudachirou, M., Ongoke, R. P., Ouamba, J. M., Silou, T. Comparative chemical and analysis properties of essential oil of Cymbopogon nardus (L) Rendle of Benin and Congo. Afri $J$ Tradit Compement Altern Med. 2007, 4, 267-272. 